\title{
SunLine Begins Extended Testing of Hybrid Fuel Cell Bus
}

S outhern California's SunLine Transit Agency has been serving passengers in and around Palm Springs for more than 30 years. For about half that time, SunLine has used alternatively fueled buses running primarily on compressed natural gas $(\mathrm{CNG})$. Today, the agency is increasing its commitment to environmentally friendly alternative power systems by testing a prototype hybrid fuel cell bus.

SunLine's experience with gaseous fuels began in 1994, when a concern for regional air quality led the agency to replace its entire diesel fleet with CNG buses. For this to happen, the agency needed (and obtained) the complete support of its staff, including managers, operators, and maintenance personnel. In 2006, SunLine began demonstrating and testing a prototype hybrid fuel cell bus developed by UTC Power, ISE Corporation, and Van Hool. During the first two years of the demonstration, the bus accumulated nearly 45,000 miles and 3,500 hours of operation.

\section{SunLine's Fuel Cell Bus Demonstration, 2006-2007, by the Numbers}

\begin{tabular}{|l|c|}
\hline Demonstration period & Jan. 1, 2006-Dec. 31, 2007 \\
\hline Miles accumulated & 44,893 \\
\hline Hours on FC system & 3,442 \\
\hline Hydrogen consumed, $\mathrm{kg}$ & 6,268 \\
\hline Average fuel economy, miles/kg & 7.16 \\
\hline $\begin{array}{l}\text { Average fuel economy, miles/ } \\
\text { diesel gallon equivalent }\end{array}$ & 8.09 \\
\hline Average speed, mph & 13.0 \\
\hline
\end{tabular}

The U.S. Department of Energy's National Renewable Energy Laboratory (NREL) is working with SunLine to evaluate this bus to help determine the status of hydrogen and fuel cell systems and associated hydrogen infrastructure in transit applications. To provide a baseline, NREL collects performance data and compares the results to those for buses that use a conventional technology, such as a combustion engine. Results are published at regular intervals and are available on NREL's Web site.

\section{SunLine's Role as Technology Demonstrator}

SunLine has taken advantage of its unique capabilities and experience with gaseous fuels, its small size, and its hightemperature/low-humidity location to attract testing projects with government and manufacturing partners. Many projects

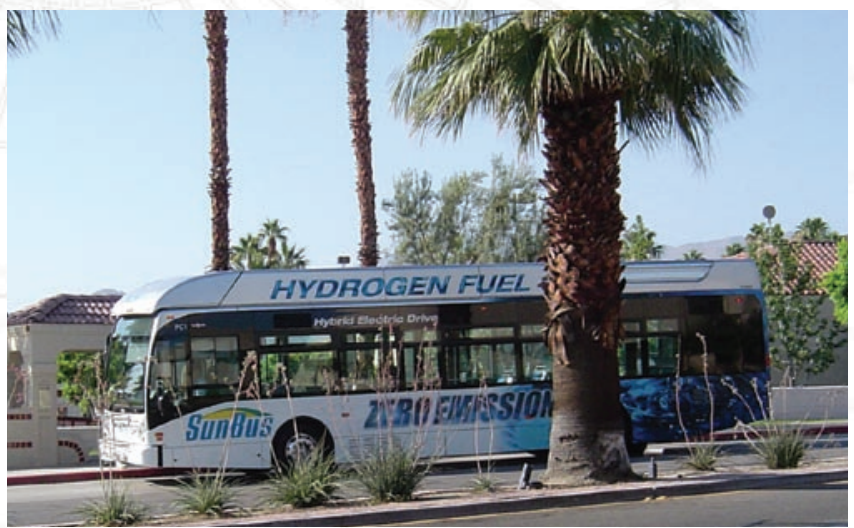

have involved natural gas, hydrogen, fuel cells, and various combinations of those technologies and associated infrastructure; the objective is to advance clean transit bus propulsion systems and leverage project funding to afford SunLine additional equipment and infrastructure.

The SunLine agency is particularly valuable to testing partners because of its willingness to push new technologies toward their limits and operate the buses as much as possible. For example, the hybrid fuel cell bus has been driven more than 2,000 miles per month for nearly half of the initial two-year demonstration period. January 2007 was a particularly active month; the bus was operated in service almost every day and accumulated over 5,000 miles and nearly 400 hours on the fuel cell system. To date, no other fleet has achieved this level of operation with a fuel cell bus. This operating regime, especially in a desert climate, is extremely valuable to a manufacturer wanting to validate the durability of its product design.

Throughout the initial demonstration period, project partners learned a great deal about the fuel cell propulsion system and how it operates in a hot desert climate. These "lessons learned" have helped to further optimize and refine the overall system as well as individual components. The initial phase of the demonstration is now complete, and the project partners are looking at the next upgrade of the fuel cell power system to determine what effect additional changes have on life and durability.

In April 2008, UTC Power installed the newest version of the fuel cell power system in the bus at SunLine, aiming to operate it for another two years. SunLine plans to operate the bus at least 8 hours per day, 7 days per week. Additional operation time is being considered, depending on reliability and durability 


\section{SunLine Hydrogen Experience Timeline}
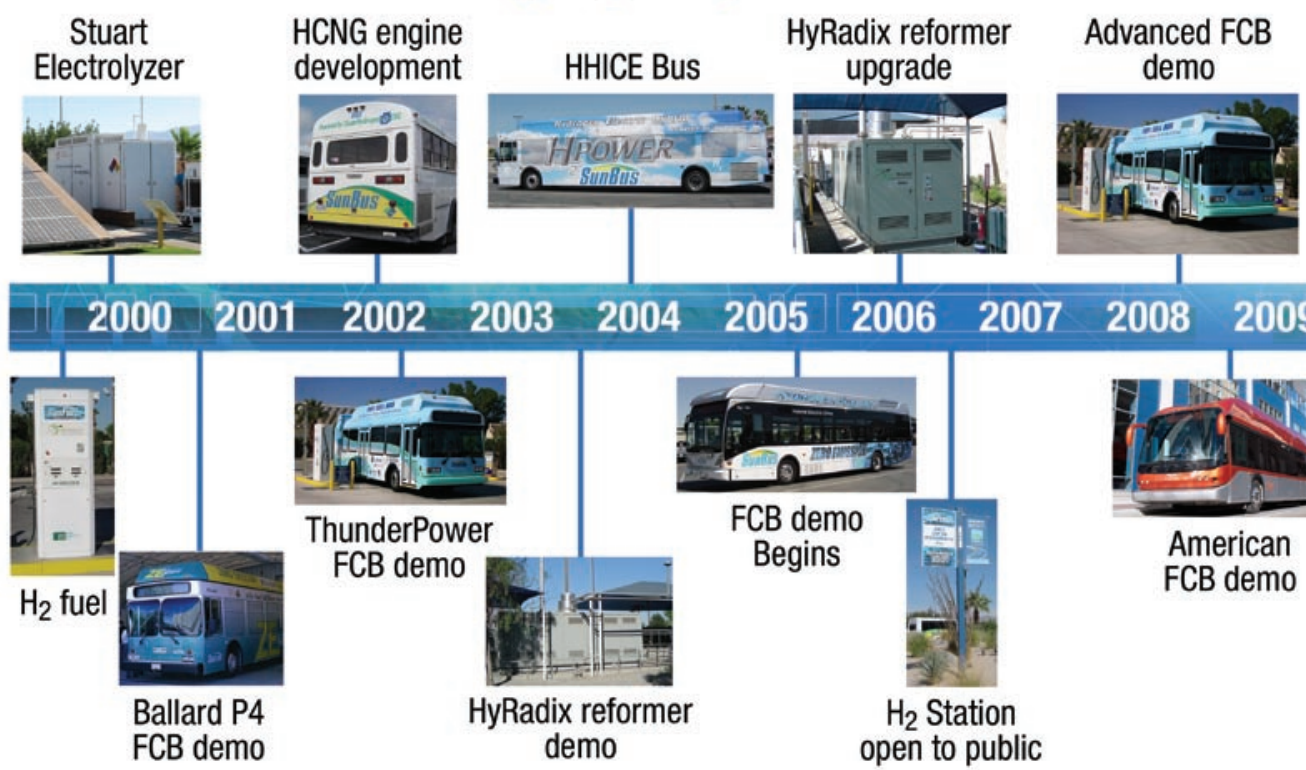

of the batteries that make up the energy storage system.

The agency is concerned, however, about the difficulty of sustaining new technology introductions and demonstration projects over time. For SunLine, it is very important to continue the project in order to learn as much as possible from the initial investment and to understand longer term issues concerning operation and reliability. Ongoing funding has been the biggest challenge, and near the end of the initial demonstration period, SunLine began

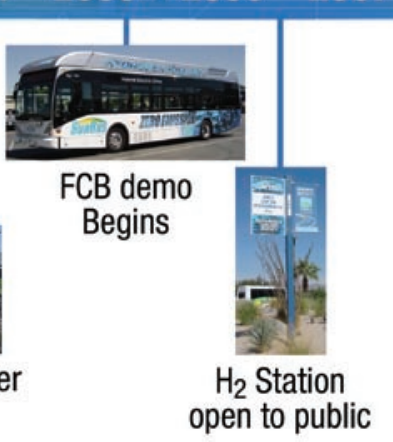

investigating ways to obtain the funding needed to continue on. Fortunately, the Federal Transit Administration (FTA) and the South Coast Air Quality Management District (SCAQMD) have provided funds for the next phase of testing.

NREL continues to work with SunLine to evaluate this latest version of the hybrid fuel cell bus. The results will be documented to show the progress being made in advancing this technology toward commercialization.

\section{Future Fuel Cell Bus Projects at SunLine}

Advanced Fuel Cell Bus Project: In 2002, SunLine tested an early prototype hybrid fuel cell bus in service for 6 months. The system was designed by ISE Corporation on a 30 -foot Thor bus chassis. As a follow-up project, SunLine plans to demonstrate this bus with a new hybrid fuel cell powertrain under funding from the California Air Resources Board, SCAQMD, and the FTA. ISE Corporation is leading the design process and including the newest fuel cell design from Ballard and advanced lithium batteries. The bus is expected to be ready for service in 2009 and will operate for at least 2 years.

American Fuel Cell Bus Project: Funded under the FTA's National Fuel Cell Bus Program, SunLine is leading a team to develop a fuel cell bus that meets "Buy America" requirements. The design features a number of advances that are expected to result in a highly efficient bus:

- Lightweight U.S.-built bus body

- Advanced windows to reduce interior heat

- Advanced energy storage and new power electronics

- High-efficiency accessories

- Newest-generation fuel cell.

Project partners include ISE Corporation for the hybrid system and integration, UTC Power for the fuel cell power system, and New Flyer for the advanced bus chassis design. The demonstration is part of a portfolio of projects for the Pasadena-based WestStart-CALSTART consortium.
Increase Your H2IQ!

Visit www.hydrogen.energy.gov

Produced by the National Renewable Energy Laboratory (NREL)

NREL is a U.S. Department of Energy National Laboratory operated by Midwest Research Institute • Battelle

DOE/GO-102008-2610

June 2008

Printed with a renewable-source ink on paper containing at least $50 \%$ wastepaper, including $10 \%$ postconsumer waste. 